\title{
PREFACE TO THE 2013 EDITION
}

he first edition of Caring was published in 1984. In the intervening
years, interest in the ethics of care has grown substantially. On my own
library shelf, there are now books and articles on care theory in philosophy, psychology, religion, bioethics, library science, peace studies, art, anthropology, education, and business. Some of the initial fears about caring have been allayed; for example, few critics now worry that attention to caring as a way of life will send women back to the kitchen and the nursery. But some genuine concerns remain, and a few important misunderstandings and differences of opinion have grown over time. In this preface, I will address some of these misunderstandings and attempt to respond to critics. In an afterword, I suggest a program for future work on care ethics.

One important complaint-with which I heartily sympathize-focuses on the former subtitle of Caring: A Feminine Approach to Ethics and Moral Education. Hardly anyone has reacted positively to the word feminine here. In using it, I wanted to acknowledge the roots of caring in women's experience, but using "a woman's approach" rather than "feminine" risked the complete loss of male readers. With "feminine," at least a few male Jungians wrote to say that they felt included. I think critics are right, however, to point out that the connotations of "feminine" are off-putting and do not capture what I intended to convey. Relational is a better word. Virtually all care theorists make the relation more fundamental than the individual. Virginia Held comments: "The ethics of care ... conceptualizes persons as deeply affected by, and involved in, relations with others; to many care theorists persons are at least partly constituted by their social ties. The ethics of care ... does not assume that relations relevant for morality have been entered into voluntarily by free and equal individuals as do dominant moral theories."

Persons as individuals are formed in relation. I do not, however, want to lose the centrality of women's experience in care ethics, and I've tried to make the connection more explicit in both Starting at Home: Caring and Social Policy and The Maternal Factor: Two Paths to Morality. ${ }^{2}$

I have called the language used in Caring the language of the mother, as 
contrasted with that of the father. Carol Gilligan gave us a powerful introduction to this contrast in her groundbreaking book, In a Different Voice. The language of the mother concentrates on relationships, needs, care, response, and connection rather than principles, justice, rights, and hierarchy. As Gilligan put it: "The ideal of care is thus an activity of relationship, of seeing and responding to need, taking care of the world by sustaining the web of connection so that no one is left alone." 3

But the emphasis on "taking care" has led to some misunderstanding and confusion. Briefly, the problem is that some proponents of care ethics have equated caring and caregiving. The ethics of care is a rapidly developing normative moral theory. It is concerned with how, in general, we should meet and treat one another-with how to establish, maintain, and enhance caring relations. Caregiving is an important element in care ethics, but, as a set of activities or occupation, it can be done with or without caring. We all know of cases in which persons assigned to provide care have performed the tasks of caregiving without conveying care. Still, I have argued that well-supervised practice in caregiving may act as an incubator for the development of caring. Thus, it is important for the young, in addition to being cared for, to see and assist in the genuine caring done by adults.

Another important source of confusion is the distinction I have made between caring-for and caring-about. Caring-for describes an encounter or set of encounters characterized by direct attention and response. It requires the establishment of a caring relation, person-to-person contact of some sort. Caringabout expresses some concern but does not guarantee a response to one who needs care. We are all familiar with an array of scenarios that might be called "caring-about." I might, for example, care about civilians living in fear during civil strife in, say, Syria, but I may not follow up on my expressed concern. Or I may follow up with a small gift to a charitable organization. Edging closer to caring-for, I may check on the credentials of the organization to find out how my contribution is spent. The point is that we cannot care-for everyone; we are limited by time, resources, and space. My comment that we have no obligation to care-for the starving children of Africa generated outrage in many readers. But we cannot be obligated to do the impossible, and it is clearly impossible to establish a caring relation with everyone in the world.

One critic, Barbara Houston, said that when she read my comment about our having no obligation to care for the starving children of Africa, her "urge was to throw the book across the room." She explained her outrage in a publication addressed to me: "I was incensed that someone should deny an obvious obligation. Upon cooler reflection I realized you were drawing a useful distinction 
between caring for and caring about, and more to the point, I discovered something about myself, namely, that I wanted to fiercely insist I had an obligation that, in all honesty, I had to admit I never made any effort to meet."4

The distinction recognized by Houston, a generous critic, is important when we discuss the function of institutions and large organizations in supporting caring. A school, for example, cannot care-for directly, but it can work toward establishing an environment in which caring-for can flourish. The same is true of international organizations and nations. One nation cannot itself care-for another, but it can encourage an environment in which groups meet face-toface and thereby create opportunities for genuine caring-for. I'll say more about this in the afterword, where we'll consider further work that needs to be done in care ethics. I think critics are right when they advise that much more must be said on caring-about.

Readers should also be alert for what we might call pathologies of care. Charles Dickens's Mrs. Jellyby comes to mind; she was so immersed in caringabout an Indian tribe overseas that she virtually ignored her own children. ${ }^{5}$ At the opposite extreme, we find parents so wrapped up in their own children that they cannot respond to - or even give attention to- others they may encounter. ${ }^{6}$

Care theorists, like virtue ethicists, put limited faith in principles. We not disdain principles. We recognize that principles-for example, an injunction against lying - help to keep daily life running smoothly. We learn the rule and commit ourselves to it, and for the most part we would not consider breaking it. However, when a real conflict arises, the principle is of little help. We have to dig behind the principle to see what deeper value has engendered it. Most of us would not consider adopting the rule as an absolute; we would not join Kant in refusing to lie to a would-be murderer even to save the life of the victim. Instead we ask who might be hurt, who might be helped by our lie. ${ }^{7}$ We acknowledge that everyday life would be harder if we did not regularly tell some considerate "white lies."

The first three chapters of Caring are devoted to an analysis of caring relations and the part played by carer (one-caring) and cared-for in those relations. Primary attention in these chapters focuses on natural caring, the caring motivated by love or inclination. It is not an exaggeration to say that relations of natural caring are treasured in every facet of human life. Such caring may require monumental physical or emotional effort, but it does not require a moral effort; that is, we act out of inclination, not out of duty or concern for the status of our character. Such caring, I argue, is the social condition we treasure and want to establish or preserve. Only when natural caring fails or cannot be invoked do we turn to ethical caring. In taking this position, we pose another 
challenge to the Kantian emphasis on adherence to principle and duty. For Kant, acts done out of love or inclination earn no moral credit. To behave morally, the Kantian moral agent must identify and act on the appropriate moral principle. Reason must displace emotion. In care ethics, however, we are not much interested in moral credit. We are, rather, interested in maintaining and enhancing caring relations - attending to those we encounter, listening to their expressed needs, and responding positively if possible. But even when we must deny the need expressed, we try to do so in a way that will preserve the caring relation.

Chapter 2 opens with a brief discussion of empathy. There I contrast empathy, originally defined as projective and cognitive, with the receptive feelingsympathy - associated with caring. In the past decade, interest in empathy has grown to the point that it has crowded out mention of sympathy. Indeed, in some current work it tends to displace the much more complex concept of caring itself. In the afterword to this edition, I raise several questions about empathy and its relation to caring, for example: What is the connection between attention and empathy? What is empathic accuracy and how important is it? What generates empathy? Does a positive response always follow empathy? Is empathy directed at a person or at a condition?

Chapters 4-6 treat ethical caring and how it is motivated by our longing for and commitment to natural caring. As in natural caring, the focus of ethical caring is relation. Virginia Held writes: "I see the ethics of care from as fully a normative view as any other ethic. It addresses questions about whether and how and why we ought to engage in activities of care, questions about how such activities should be conducted and structured, and questions about the meanings of care and caring. It especially evaluates relations of care." 8

From the perspective taken in this book, natural caring is the motivating force behind ethical caring. When something goes wrong (or might go wrong) in our relational encounters, we want to restore or maintain natural caring. To do this, we draw on what I have called our "ethical ideal," our memories of caring and being cared for. We ask how we might act if this other were not so difficult, if the situation were less complicated, if the burdens were not so great, if we were at our caring best. And through this often challenging process of reflection, we decide what to do, how to respond.

Ethical caring, then, derives its strength from natural caring. This is clearly a reversal of Kantian priorities. Ethical caring does not seek moral credit; it seeks a response from the cared-for that completes the encounter-a recognition that is usually spontaneously offered in natural caring. Natural caring is the cherished condition; ethical caring seeks to restore or replace natural caring. 
There is reason to be cautious here. Striving to maintain natural caring does not imply that we respond positively to every expressed need. Indeed, there are many situations in which it would be clearly wrong to do so. There are times when we must deny an expressed need, sometimes for the sake of the cared-for, sometimes out of concern for others in the web of care. The attempt to maintain a caring relation is an attempt to keep the doors of communication open, and this can be especially important when the status of basic relations is ambiguous or even questionable. It is especially important in the context of global caring.

The process is open to corruption. Ethical caring is hard work that requires continuous reflection on the part of carers. How can I best care for the one before me without damaging other relations in the web of care and without engaging in deceptions that might eventually undermine future encounters? I'll return to this topic in the afterword, which explores the possibilities of global caring.

Chapter 5 concentrates on the construction of the ideal upon which we draw in ethical caring. As John Dewey advised us repeatedly, our ideals are properly created and developed from the "real stuff" of life. They are neither handed down from the gods nor fashioned from imaginary or fanciful elements. This is why the real stuff of childhood experience must be so closely guided in caring relations. Memories of being cared for and reflections on such care constitute the early material of the ideal. Then, as the child learns to care for others, new memories are added to the developing ideal. Emphasis throughout the chapter is on the continuous development of that ideal, including the incorporation of errors and lapses in caring together with the honest reflection on them that increases the real usefulness of the ideal.

Sometimes when we become aware of our relatedness-when reciprocal receptivity is at its height—we experience joy. Existential philosophers have rightly described the anguish and anxiety that accompany human life, and I certainly do not deny these feelings. They accompany us, unbidden, through a lifetime. However, joy-discussed in chapter 6-offers itself as an unsummoned reward or by-product of relation. It seems to be triggered by receptivity, an openness to the other that is somehow reciprocated in an almost mystical fashion. We are momentarily overwhelmed by a feeling of joyful oneness with this other-our child, our lover, an idea, a scene, a piece of music. Joy helps to maintain us in caring and, thus, adds to our ethical ideal.

In chapter 7, I explore forms of receptivity and response that shade off from the ethical into the intellectual. It is not surprising that, with respect to nonhuman animals, we relate most closely to those that respond to us with seeming interest and affection. Such response is exactly what care ethics refers to as 
reciprocity. We are not talking about contractual reciprocity. We do not expect cared-fors, whether human or animal, to do for us what we do for them, nor do we expect payment of some sort. Instead, we look for signs that our caring has been received. What we do by way of caring satisfies a need in the cared-for, completes the caring relation, and enriches our lives as carers.

I have a long-standing interest in intellectual receptivity, which has grown over my years as a teacher. I have included some discussion of it in chapter 7. When we hear Archimedes's exclamation, “Eureka!," we note a joyous recognition of intellectual receptivity. An idea has responded to his investigation. I mention in an early chapter Mozart's "hearing" music played to him from somewhere in the unseen world of musical ideas, Miró's hand mysteriously guided as he painted, the mathematician Gauss seized by mathematics, a mathematics student astonished by what she saw when she stopped thinking and received what was there in the written problem. Receptivity can be experienced in both moral and intellectual domains.

There are clearly parallels between intellectual and moral receptivity, but there are also distinct differences. Simone Weil, whose work on attention is important in care ethics, made the mistake of assuming that the practice of attention could be cultivated in one field and transferred to another. She suggested, for example, that the study of geometry could encourage the capacity for attention in general and, in particular, for attention to God. That attention might then be redirected to human beings. ${ }^{9}$ I think she was wrong on this. Some highly receptive composers, artists, and mathematicians have been demonstrably insensitive to the needs and feelings of human beings. We are not likely to increase the receptivity characteristic of caring by insisting that all children study geometry. To develop as caring persons, young people must have supervised practice in caring.

The last chapter treats moral education. In it, I identify four major components of moral education: modeling, dialogue, practice, and confirmation. Most approaches to moral education mention the first three, and the responses of readers over the years have been largely favorable to my interpretation through care ethics. Differences in emphasis have been debated-especially those between character education and care ethics - but no serious objections have been raised against the treatment of modeling, dialogue, or practice. ${ }^{10}$

Little has been said, however, about confirmation, a concept adapted from Martin Buber. ${ }^{11}$ In discussing this deeply compassionate idea, I have emphasized attributing to the wayward acts of students and children "the best possible motive consonant with reality" (193). Instead of blaming, shaming, and pun- 
ishing, we try to find a respectable motive for a less-than-respectable act. In doing so, we point a student toward his or her best self, toward a developing ethical ideal. This act, we advise, is beneath the better person we have come to know. The main difficulty with this approach is that teachers must come to know their students quite well. We cannot very well attribute the best possible motive consonant with reality if we are ignorant of that reality. I suspect that, understandably, teachers may feel that confirmation suggests they should gloss over infractions and simply pretend that they could have been committed for morally acceptable reasons. Such a response, however, might be worse for the developing ideal than traditional blame and punishment. To confirm another, we must know and understand that other's reality. Given the structure of today's schooling, this may be asking the impossible.

Despite the difficulties involved in employing confirmation, I would not give up on it. Rather, I would ask whether there are ways in which we might structure our schools so that teachers and students could spend more time together. Why not allow elementary school students and teachers to stay together (by mutual consent) for three years rather than one? Why not encourage one teacher to guide a group of students through all of their high school mathematics? The formation of caring relations is central in both teaching and life itself.

In what follows, the original text remains intact. I invite readers to raise questions and objections that should be added to my growing list. In the afterword, I will make some suggestions for further analytical work on care ethics.

\section{NOTES}

1. Virginia Held, The Ethics of Care: Personal, Political, and Global (Oxford: Oxford University Press, 2006), p. 46.

2. Nel Noddings, Starting at Home: Caring and Social Policy (Berkeley: University of California Press, 2002); Noddings, The Maternal Factor: Two Paths to Morality (Berkeley: University of California Press, 2010).

3. Carol Gilligan, In a Different Voice (Cambridge: Harvard University Press, 1982), p. 62 .

4. Barbara Houston, "Koans of Care," in Dear Nel, ed. Robert Lake (New York: Teachers College Press, 2012), p. 10.

5. Charles Dickens, Bleak House, vol. 2 (New York: Peter Fenelon Collier, 1853). 
6. See Ruth Groenhout, Connected Lives: Human Nature and an Ethics of Care (Lanham, MD: Rowman and Littlefield, 2004).

7. See Sissela Bok, Lying: Moral Choice in Public and Private Life (New York: Vintage, 1979).

8. Held, The Ethics of Care, p. 46.

9. Simone Weil, Simone Weil Reader, ed. George A. Panichas (Mt. Kisco, NY: Moyer Bell, 1977), pp. 44-52.

10. For more on this, see Nel Noddings, Educating Moral People (New York: Teachers College Press, 2002).

11. Martin Buber, I and Thou, trans. Walter Kaufmann (New York: Charles Scribner's Sons, 1970). 